\title{
電飾アドバルンの 話
}

正会員大山幸 民*

\section{1. 広告用アドバルン}

“空には今日もアドバルン”といわれている広告用アド バルンも，ついこの間までは宣間だけのものであつたが

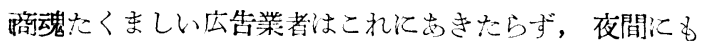
これを利用っること考考て，ついに電飾アドバルンが 生れた。

居間使用の公告用アドバルンは，一般のもので法，ア ドバルンの力綱に広告交字をつける網を設け，これ江種 々の色布で字形を作ったもの在，如たものである が，夜間使用の電飾アドバルンは，是間汇使用する色布

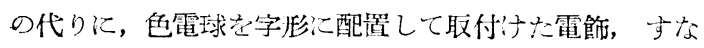
わち電気サインで古る。

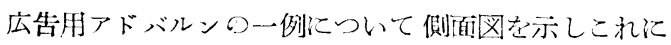
つき述べると次の通りである。

\section{2. アドバルン}

アドバルン (去告気球) の風袋は、ビニールで製作さ

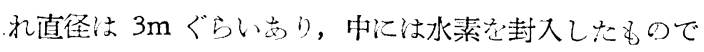
ある。この程度のアドバルンは, 重さ $15 \mathrm{~kg}$ 位のものを 浮揚する力があり, 麻製の直径 $5 \mathrm{~mm}$ 位の力網で保持さ

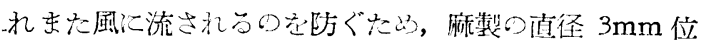
の支線が設けら礼る。

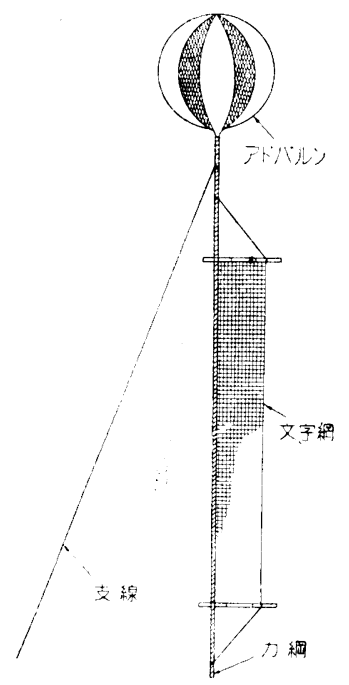

第1図交字網

\section{3. 交字網}

色布交字去圷法電飾を取 付计万網络力綱つ中途江装 置され交字緗といわれる。 この交字網のわく絲法麻製 の直径 $2 \mathrm{~mm}$ 位で, 綃絲化 はタコ絲が使用され，また 交字網は幅だしのため網の 上端と市端に竹製の棒が䛧 用されている。この文字網 の大きさは，長さ $10 \mathrm{~m}$, 幅 $1.3 \mathrm{~m}$ 位を普通とする。

\section{4. 文字網の装置替} アドバルン, カ緝, 支線 は，笪夜り別なく共用する ものであるが，文字網注寔

* 東京電力株式会社 - 配電課

間では電飾（電気サイン）でなく，たよ゙文字網に色布の 字形をこりつけたものを使用し，夜間冲電飾で文字網に 色電球を字形にとりつ忛たもの学使用与る。

したがって交字網恃朢間用と夜間用とで，それぞれ装 置替をしなければならない。

\section{5. 電飾装置の一例}

電飾装置の一例を示すと次の上うである。

(1) 電源 電源は $100 \mathrm{~V}$ の電灯回路を使用する.

（2）容最 電飾の容量结500W程度である。

(3) 電球 電球と乙ては, 豆電球老 $100 \mathrm{~V}$ 亿対し25個く らいら゙つ直列に峖続し, 豆電球の総数は 1200 個位で, 交字網糸で結びつけられる。

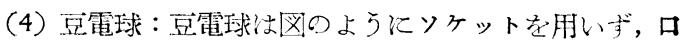
金の中央挨触子にリード線として, 長さ $6 \mathrm{~cm}$, 太さ $0.75 \mathrm{~mm}^{2}$ のビニールコードが牛田づけし てまって,このリード線の先には太さ $0.5 \mathrm{~mm}$ の裸銅線で $\Omega$ 形の摸触輪がつけてある。この

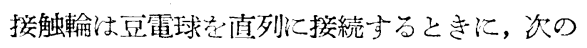
豆電球の口金にハメコむためのるのである。ま た口金には事故防止のため，ビニールのチュー ブが汪迄んである。

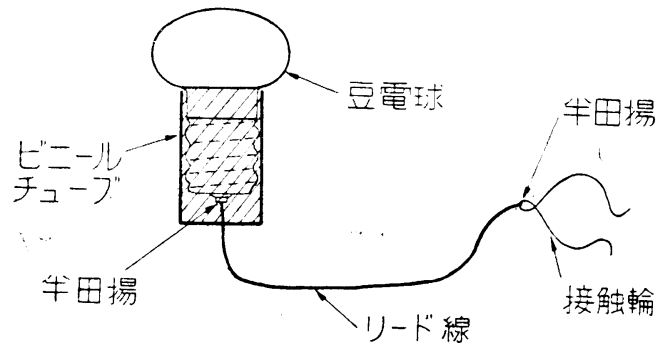

第 2 図豆電球

（5）配線：文字網にとりつけられた豆電球への配線に

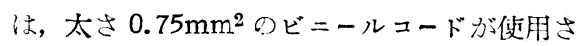
れたるまないように $30 \mathrm{~cm}$ 内外の間隔に系 で結じつけてある。

\section{6. 電飾アドバルンエ事基準}

以上で電飾アドバルンの一例について概要を述へたが この電飾アドバルンは，2年ばかりま交から，諸所で乐 揚しているのを見受㣔る。しかし，これは電気工作物規 
程の制限外工事にあたるので，表向きには許容されてい ないるのなのである.

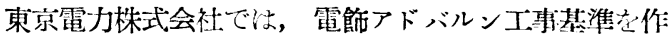
製して， その朌に昨年（昭和28年）の12月に，特殊設計 諗可の川請をしたところ，次の上うな番号で認可指令が あつた。

29公第243号 (29.3.4) 通街库業大臣惢可

29東産公第2429号（29.3.18）東京通陾座業局長指令 よって, 諗可のあった電飾アドバルン工事基準を次に 揭げて参考に供する。

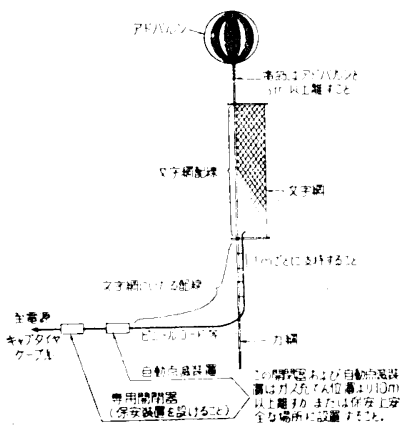

6. 電飾アドバ ルン工事基準

1. 適用䡉囲：この 工事基淮标，広告 用アドバルンの文 字絧に電飾する工 事心適出吉。

2. 対地它圧：回路 の刘地電牢结 150 V以下でなければ

第 3 困雷飾アドバルン装虽図 ならない。

3. 分些回路：15A 以下の自動遮䉼器で保護する分岐 回路で使用しなけれ济ならない。

4. 專用開閉器：回路にはいつでも開閉すらことので きる專用開閉器および自動遮䉼器をけい留点の近く に設けなければならない。

この專用開閉器および自動遮䉼器はガス充てん位 置上り $10 \mathrm{~m}$ 以上㒕与か，または保安上安全小場所
に設置すること。

5. 霞灯：電灯は次の备号によらなければならない。

（1）電灯は充電部を露出しないよ5適当に絕縁する。 こと.

（2）電灯は文字網にビニールテープ，またはその他 の絕縁性の\&ので確実に取り付けること。

(3) 電飾洼ドバルンの下方に取り付け，これら相 互問は $3 \mathrm{~m}$ 以上離すこと。

6.配線：配線は次の各号によらなけれでならない。

（1）電源より専用開閉器にいたる間の配線は，太さ $0.75 \mathrm{~mm}^{2}$ 以上のキャブタイヤケーブル在使朋する こと.

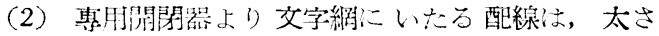
$0.75 \mathrm{~mm}^{2}$ 以上のビニールコード等を使用し.引上 部分は力䊼こ $1 \mathrm{~m}$ 少きに確実に取りつけること.

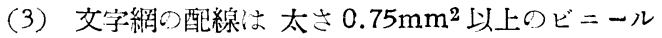
コード等埊使用し，交字䋧にビニールテープ，ま たは絶縁性のもので $60 \mathrm{~cm}$ 以下ごとに， むた分岐 点に恔持点芯設计，張力のか」らない上うにす ること。

（4）電線の接続点は牛田㢳げを行うか，または接続 器を肋い，颃続点にはビニールテープ巻きな施す こと.

7. 自動点隇装置：自動点隇装置を施設する場合は, 專用閐閉器に绦接して負荷側に設置しなければなら ない。

この自動点減装置牥，ガス充てん位置より $10 \mathrm{~m}$ 以 上離与かまたは保安上安全な場所に設置すること。

$$
\text { (29-8-19受付) }
$$

资料

照明学会雑誌第38巻各号の

表紙色のマンセル値の実測

\begin{tabular}{|c|c|c|c|c|c|c|}
\hline 号 & \multicolumn{2}{|c|}{ 目 } & 䤃 & 笑 & & 測 \\
\hline 1 & 10 & $\mathrm{R}$ & $6 / 3$ & 7 & YR & $6.7 / 4.5$ \\
\hline 2 & 10 & $\mathrm{R}$ & $4 / 2$ & 5 & YR & $4.5 / 2$ \\
\hline 3 & 7.5 & GY & $6 / 3$ & 7.5 & GY & $7.0 / 4$ \\
\hline 4 & 7.5 & GY & $4 / 2$ & 7.5 & GY & $3.7 / 2$ \\
\hline 5 & 2.5 & $\mathrm{G}$ & $6 / 3$ & 2 & $\mathrm{G}$ & $6.7 / 3$ \\
\hline 6 & 2.5 & $\mathrm{G}$ & $4 / 2$ & 2.5 & $\mathrm{G}$ & $4.5 / 2.5$ \\
\hline 7 & 5 & $\mathrm{~B}$ & $6 / 3$ & 5 & B & $6.2 / 3$ \\
\hline 8 & 5 & $\mathrm{~B}$ & $4 / 2$ & 5 & B & $3.7 / 2$ \\
\hline 9 & 5 & $\mathrm{P}$ & $6 / 3$ & 5 & $\mathrm{P}$ & $6.0 / 2.5$ \\
\hline 10 & 5 & $\mathrm{P}$ & $4 / 2$ & 5 & $\mathrm{P}$ & $4.3 / 2$ \\
\hline 11 & 5 & YR & $6 / 3$ & 6.5 & YR & $7.0 / 5$ \\
\hline 12 & 5 & YR & $4 / 2$ & 2 & YR & $5.2 / 4$ \\
\hline
\end{tabular}

註”平均值，個差の範囲はHでは土1.0,Vでは土0.5, C では土0.5

（正会員 森 於礼） 
照明サロン

\section{歌人北原白秋の色彩感覚}

正会員 木村 俊 夫*

\section{1. 白秋の感覚的素算}

一般に北原白秋诂感覚詩人で出るといわれている。確 かにその通りである。彼の処女詩集 “牙腙門”や処女歌 集“桐の花”梳，一踓彼の存在走示し，その地位を確立. させた作品であるが，人々が警慔したことの一つは，そ

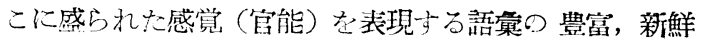

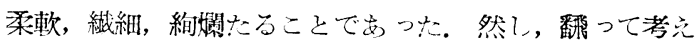
るに，かかる語咸が豐富，一であるということは感覚 体験そのものが豊富，一であったことを意味する，白 秋はこうした素筫在持っていたのである。

“桐の花“に收められた小評論 “桐の花とカステラ” は上述の素質を集約的に示すものと言ってよいが，そこ ではいわゆる五官に属する諸感覚語が短い文章の内にギ ツシリと詰委っている．仮りにその第1節を取上げてみ ろ. ここに注 356字ある。 その中に既に感覚用語が数箇 用いられており，五官は全部挙げられている。

諸感賞の中でいずれが最も優勢であるかは速断を許さ 妨，視感覚，分けても色彩感覚は少くとも他の歌人之 此較する時, クッキリとその優越を示すのである。

\section{2. 豐かな色彩感覚}

(1) 色彩鿉数の豊かさに見る。

歌人白秋の色彩感覚の豊かさ在他の歌人のそれと比較 する最も確実なる方法は，双方の色彩語使用率を比較す ることである。そこで, 全生涯に互る作品（と言ってぬ 結局抄本に頼る住かないが）におけっ色彩話の頻数を歌 数で除したるのを比較する，という方法を用いるのであ るが，その一端を示すと次ぎの如くである。

第 I表 白秋と他の歌人との色彩語使用率の比較 欨人 色彩語数 歌数 使用率歌集名 北原白秋 $1060424724.96 \%$ 白秋歌集 (河出書房) 長塚 節 18381922.34 長塚節歌集 (岩波文庙) 与謝野晶子・ 544296318.33 与謝野晶一歌集(岩波文庫) 古泉千樫 13499813.43 古泉千樫歌集（創元社） 正岡于規 10396610.66 于規歌集 (岩波文庫)

表によれダ白秋が首位を占めている。

(2) 色彩語の種類の豊かさに見る.

前項のように\%を以て示吉程の確実さは求められ妨 色彩感賞の豊かさを示すも5一つの方法は，色彩語㚜の 種類の数を以てするやり方である，調查の際のテキスト

* 茨城大学
は前項と同じである。

第 2 表 白秋乞他の磁人との色彩語策数の比較 歌人 赤橙黄緑青紫白兏黑金銀計 白 秋 $\quad \begin{array}{llllllllllll}15 & 3 & 3 & 7 & 10 & 4 & 1 & 2 & 3 & 4 & 5 & 57\end{array}$ 節 $\quad \begin{array}{llllllllllll}2 & 1 & 1 & 0 & 2 & 1 & 1 & 0 & 1 & 0 & 1 & 10\end{array}$

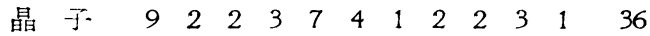
千 慜 $\quad \begin{array}{llllllllllll}2 & 0 & 1 & 2 & 3 & 1 & 1 & 2 & 1 & 0 & 1 & 14\end{array}$

于 替 $\quad \begin{array}{llllllllllll}4 & 0 & 1 & 1 & 3 & 1 & 1 & 1 & 1 & 0 & 1 & 14\end{array}$

$\begin{array}{lllllllllllll}\text { 計 } & 19 & 6 & 4 & 9 & 17 & 7 & 1 & 6 & 4 & 5 & 5 & 83\end{array}$

語受の種類数においても白秋が断然押えている。晶子 が第 2 位にあるのはさすがで岕る。節は色彩語使用率で は第 2 位なのに 語策数では未位である。かかるところか ら，各々の歌集が作り出す色彩世界一之れはまた各々 の歌人の眺めるこの世界の色を現わすものであるがの配色構造も問題とされてよい。

\section{3. 色彩世界の特徽}

（1）基謂色

先ず各々の歌人の色彩世界の構造を示そう。そのため には备々の歌集中に見られる色彩語の色別の\%を捉克れ ばよい。

各歌人に於いて第 1 位，第 2 位を占めるものは赤また は白であるが 白秋では赤が第 1 位，白が第 2 位である。 この赤と白で全体の約 60\%告めるから，その色彩世界 の基調色は赤と白である，と言兄る。

（2）多彩絢爛

色彩語使朋苴に於いては白秋と節では大差はない，乙 かし，節の歌を多彩絢橍と感ずる人は先ずないようであ ろ. 省しろ，色彩に之しい，というのが多くの人の印象

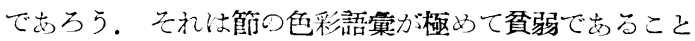
も通じ，また白の極端に豊富なことと夕通ずる。これに 対して白秋恃全く刘蹠的である。白秋と雖も白は決して 少くはないが，金，銀をも含めて総ての色を色彩世界に 收めている。功る点が白秋の色彩世界を絢閣たらしめ らのであるう。

\section{4. 色彩世界の年代的変遷}

上述の色彩世界は，各々の敬人の生涯を压縮间定した ものとして取出したのであるが，各々の歌人はかかる色 彩世界に見られる如き構造を生涯に互って持続けたので はない，白秋にしてもそうである，生涯の間に幾変要か しているのである。次ぎに，白秋例をとってかかる变 
第 3 表 白秋々他の歌人々の色彩世界の構造の比較

\begin{tabular}{|c|c|c|c|c|c|c|c|c|c|c|c|c|}
\hline & 赤 & 橙 & 黃 & 緑 & 青 & 紫 & 白 & 灰 & 黑 & 金 & 銀 & 竍 \\
\hline 秋 & 33.7 & 0.5 & 6.9 & 7.5 & 7.7 & 3.6 & 24.4 & 0.2 & 11.0 & 3.0 & 1.5 & $100.0 \%$ \\
\hline 節 & 14.2 & 12.0 & 7.7 & 19. & & 0.5 & 45.4 & 0.0 & 0.5 & 0.0 & 0.0 & 100.0 \\
\hline नj. & 18.34 & 0.36 & 4.41 & 0.72 & 15.62 & 9.0 & $41.9 !$ & 0.00 & 6.62 & 2.98 & 0.00 & 100.0 \\
\hline 樫 & 31.34 & 0.00 & 3.73 & 5.22 & 14.94 & 2.23 & 27.61 & 0.00 & 11.95 & 2.98 & 0.00 & 100.0 \\
\hline 嫢 & 31.07 & C. 00 & 3.88 & 21.36 & 5.83 & 8. 74 & 24.27 & 000 & 4.85 & 0.00 & 0.00 & 100.0 \\
\hline
\end{tabular}

第 4 表 白秋の各歌集の年代区分及び各年代の特徵

\begin{tabular}{|c|c|c|c|c|c|}
\hline 歌集各 & 年代時期 & 年代名 & 制作年齟 & 纵活・境遇等 & 歌 風 \\
\hline 桐 の花 & I & 桐の花時代 & $25 \sim 28$ 藏 & 新詩讴参加, 脱退, 苦恋 & 浪漫, 象徵, 官能, 異国情緒 \\
\hline 雲母 集 & II & 雲母集時代 & $29 \sim 30$ & 三崎, 父島, 帰京, 窮乏 & 力と熱の奔滕 \\
\hline $\left.\begin{array}{l}\text { 焦の倣 } \\
\text { 梘想の秋 }\end{array}\right\}$ & III & 雀の朐時代 & $30 \sim 38$ & 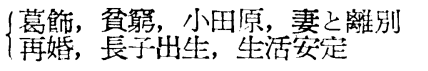 & $\left\{\begin{array}{l}\text { 東洋的幽变主義, } \\
\text { 閒寂, 簡素 }\end{array}\right.$ \\
\hline 風隱集 & IV & 小田原時代 & $39 \sim 41$ & 家庭円滿, 長女泏生 & 寬阔, 温雅, 明朗 \\
\hline $\left.\begin{array}{l}\text { 皇南風 } \\
\text { 殹 }\end{array}\right\}$ & $\nabla$ & 多宥持代前期 & $42 \sim 55$ & $\left\{\begin{array}{l}\text { 谷中, 大森, 世田谷, 砧, } \\
\text { 多磨刊行, 成城 }\end{array}\right.$ & 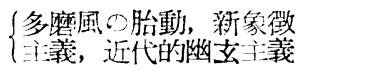 \\
\hline $\begin{array}{l}\text { 溪 流唱 } \\
\text { 燠 }\end{array}$ & VI & 多磨持代後期 & 51 & & 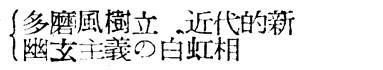 \\
\hline 墨 檜 & VII & 溥明時代 & $53 \sim 58$ & 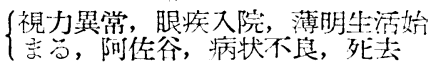 & 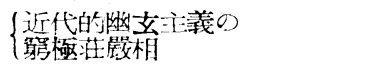 \\
\hline
\end{tabular}

第 5 表 白秋の色彩世界の年代的变遷

\begin{tabular}{|c|c|c|c|c|c|c|c|c|c|c|c|c|c|}
\hline 赤 & 橙 & 黄 & 緑 & 靑 & 紫 & 白 & 灰 & 黒 & 金 & 銀 & 色彩语数 & 歌数 & 撛数/歌数 \\
\hline $37.3 \%$ & 0.0 & 13.5 & 7.3 & 14.6 & 4.8 & 13.4 & 0.0 & 63 & C. 4 & 2.4 & 206 & 538 & $38.24 \%$ \\
\hline 56.8 & C. 0 & 0.0 & 4.3 & 3.1 & 1.2 & 8.6 & 0.0 & 5.6 & 14.2 & 6.2 & 162 & 487 & 3326 \\
\hline 36.6 & C. 9 & 1.9 & 6.7 & 7.7 & 2.9 & 39.5 & C. 0 & 2.9 & 0.9 & 0.0 & 104 & 695 & 4. 24 \\
\hline 38.5 & 1.5 & 9.6 & 11.2 & 7.6 & 1.5 & 20.8 & 0.6 & 7.6 & 1.1 & 0.0 & 197 & 767 & 5.68 \\
\hline 17.2 & 0.0 & 5.7 & 112 & 7.2 & 6.7 & 34.4 & 0.4 & 14.4 & 0.0 & 2.8 & 209 & 919 & 22.73 \\
\hline 24.2 & 0.0 & 7.3 & 2.1 & 5.2 & 1.3 & 34.7 & C. 0 & 23.1 & 0.0 & 2.1 & 95 & 299 & 31.77 \\
\hline 14.5 & $0 . C$ & 2.2 & 1.6 & 1.6 & 2.2 & 44.5 & 0.0 & 27.4 & 4.4 & 1.6 & 87 & 542 & 16.05 \\
\hline
\end{tabular}

要の跡を辿ってみよう。

（1）白秋の各歌集の年代区分及ご各年代の特徴

白秋の全生涯に就けっ歌集は没後の刊本と共に数えて 12ある。元してそ礼ら法年代的に怯 7 期に区分できる。

（2）白秋の色彩世界の年代的変要

白秋歌集中の色彩話上述の7期に分けて色彩別に\% を捉えると次の如くで岕。

上揭の表によって色彩別に年代的变化曲線を描き， そ れな年柃，境遇及ご歌風の变遷之照応させながら考察す ると，色彩世界の構造の变遷の嫢定要因が明かとなる。 その間の事情を簡単にでも紹介したいが紙面の都合上制 愛する。詳しくは“多磨”Vol.34，No.3〜5.1952 に連 載の拙稿 “歌人白秋の色彩感覚”在参照されたい。

$$
\text { (29-10-18 受付) }
$$

\section{委紙説明}

\section{給電室の照明}

中部電力株式会讴岐早支店粭電棎で纺, 采統盤照明

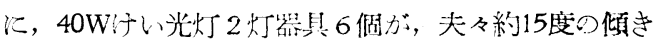

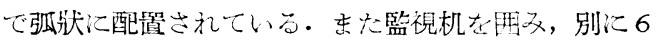
個の器具が配置され全般照明にあてら光ている。器具 はいら゙れもルーバ付器具である。

照度：水平面平均照度 約350ルクス 采統盤面照度１00〜350ルクス として計画されている。

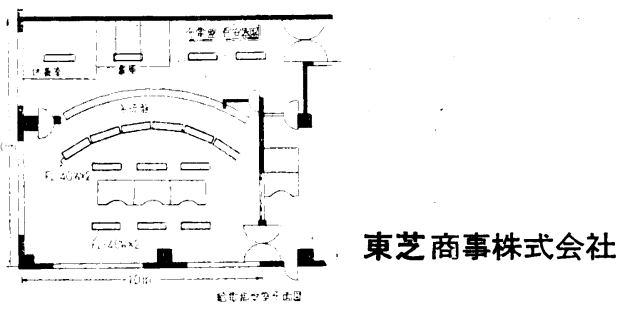

